\title{
Freeze-thaw processes and intense rainfall: the one-two punch for high sediment and nutrient loads from mid- Atlantic watersheds
}

\author{
Shreeram Inamdar 1 • Erin Johnson • Richard Rowland • Daniel Warner • \\ Robert Walter • Dorothy Merritts
}

Received: 25 October 2017/ Accepted: 16 December 2017/Published online: 20 December 2017

(C) The Author(s) 2017. This article is an open access publication

\begin{abstract}
Large runoff, sediment, and nutrient exports from watersheds could occur due to individual extreme climate events or a combination of multiple hydrologic and meteorological conditions. Using high-frequency hydrologic, sediment, and turbidity data we show that freeze-thaw episodes followed by intense winter (February) rainstorms can export very high concentrations and loads of suspended sediment and particulate organic carbon (POC) and nitrogen (PN) from mid-Atlantic watersheds in the US. Peak suspended sediment $\left(>5000 \mathrm{mg} \mathrm{L} \mathrm{L}^{-1}\right), \quad$ POC (>250 $\mathrm{mg} \mathrm{L}^{-1}$ ) and $\mathrm{PN}\left(>15 \mathrm{mg} \mathrm{L}^{-1}\right)$ concentrations at our 12 and 79 ha forested watersheds for the February rainfall-runoff events were highest on record and the fluxes were comparable to those measured for tropical storms. Similar responses were observed for
\end{abstract}

Responsible Editor: Arthur J. Gold.

Electronic supplementary material The online version of this article (https://doi.org/10.1007/s10533-017-0417-7) contains supplementary material, which is available to authorized users.

S. Inamdar $(\bowtie) \cdot$ E. Johnson · R. Rowland · D. Warner Water Science \& Policy Program, University of Delaware, 152 Townsend Hall, 531 S. College Avenue, Newark, DE 19716, USA

e-mail: Inamdar@udel.edu

R. Walter · D. Merritts

Department of Earth and Environment, Franklin and

Marshall College, Lancaster, PA, USA turbidity values ( $>400 \mathrm{FNU})$ at larger USGS-monitored watersheds. Much of the sediments and particulate nutrients likely originated from erosion of stream bank sediments and/or channel storage. Currently, there is considerable uncertainty about the contribution of these sources to nonpoint source pollution, particularly, in watersheds with large legacy sediment deposits. Future climate projections indicate increased intensification of storm events and increased variability of winter temperatures. Freeze-thaw cycles coupled with winter rain events could increase erosion and transport of streambank sediments with detrimental consequences for water quality and health of downstream aquatic ecosystems.

Keywords Extreme climate events - Tropical storms · Erosion · Sediment nutrients $\cdot$ Carbon · Nitrogen · Legacy sediments · Runoff export

\section{Introduction}

Sediment and sediment-bound nutrients and pollutants are among the leading causes of water quality and habitat impairment in our nation's water bodies (USEPA 2016a). Excess sediment can decrease water clarity and light penetration and bury valuable spawning beds, while nutrients transported with sediments can contribute to eutrophication of aquatic ecosystems (Henley et al. 2000; Waters 1995). 
Sediment input to streams and aquatic ecosystems can originate from upland sources such as erosion of cropland, urban construction sites, and unpaved road surfaces, and/or from near-stream sources such as streambank and bed erosion (USEPA 2016b; Walling 2005). Identifying these disparate sediment sources and their relative contributions to watershed sediment yields is critical given that land management and mitigation strategies differ considerably for each sediment source (Wohl 2015).

Sediment and particulate nutrient inputs to water bodies are typically at their highest during storm events (Dhillon and Inamdar 2013; Gellis et al. 2017; Jeong et al. 2012; Jung et al. 2012). The largest and most intense storms, particularly those associated with hurricanes and tropical depressions, have been found to contribute a substantial proportion of the annual sediment and nutrient export from watersheds (Dhillon and Inamdar 2013, 2014; Inamdar et al. 2015; Gellis et al. 2017). Climate data from the past 50 years for the northeast USA and projections for the future indicate an intensification of the top $1 \%$ of the storm events (Melillo 2014). While individual large or extreme events (e.g., the top 1-5\%) could produce large exports, recent studies also suggest that coupled "less extreme" hydrologic and meteorological conditions could also yield record runoff and sediment responses (e.g., Yellen et al. 2014, 2016). Yellen et al. (2016) showed that very high antecedent 30-day precipitation coupled with rainfall from tropical storm Irene yielded the highest sediment exports recorded for the Connecticut River watershed in Massachusetts, USA. This was despite the fact that streamflow associated with tropical storm Irene was not the highest on record. Thus, understanding how a variety of climatic and hydrological conditions (storm intensity, seasonal storm timing, antecedent moisture conditions, etc.) could combine to yield large sediment and nutrient exports is an important challenge and knowledge gap (see Garner et al. 2015; Naylor et al. 2017).

Climate variability and large runoff events could particularly pose a problem for landscapes with large supplies or stores of sediments and nutrients. Valleybottoms in the eastern US have been reported to contain large deposits of legacy sediments - defined as near-stream alluvial and colluvial material resulting from human-induced disturbances (Trimble 1974; James 2013). Walter and Merritts (2008) identified some of these as millpond sediments trapped upstream of numerous milldams that were built for water power along streams and rivers in the region for several centuries after Colonial settlement (late 17thearly 20 th c.). Low head milldams (typically 1-3 m) raised base level, reduced flow velocities, and resulted in substantial sediment accumulation behind the dams (Walter and Merritts 2008). Many of the dams have now breached and their upstream reservoirs eroded, resulting in highly incised contemporary streams with exposed vertical streambanks that are vulnerable to erosion (Merritts et al. 2011, 2013; Pizzuto and O’Neal 2009; Wegmann et al. 2012). Not surprisingly, studies have reported anomalously elevated rates of bank erosion and sediment exports from watersheds in the Piedmont region of the eastern US (Merritts et al. 2011; Donovan et al. 2015; Gellis et al. 2009; Mukundan et al. 2010; Stewart et al. 2015; Voli et al. 2013).

Stream-bank erosion has been found to contribute as much as $50-100 \%$ of the suspended sediment loads in Piedmont watersheds (Banks et al. 2010; Gellis and Noe 2013; Massoudieh et al. 2012; Voli et al. 2013). Fluvial erosion with large storm flows (Gellis et al. 2017); freeze-thaw activity (Couper, 2003; Lawler 1993a, b; Merritts et al. 2011, 2013; Wolman 1959; Wynn and Mostaghimi 2006) during winter and/or desiccation and cracking (Lyons et al. 2015) in summer; and mass wasting (Fox et al. 2016) have been hypothesized as some of the important mechanisms for erosion of stream-bank sediments. Freezethaw cycles cause bank sediments to lose their cohesive strength with subsequent detachment and slumping/collapse at the base of the streambank (Merritts et al. 2013; Wolman 1959; Wynn 2006). The loose, fine, detached sediment is then flushed out by streamflow and transported downstream.

Our previous observations in a mid-Atlantic, Piedmont, forested watershed with legacy sediment deposits has revealed substantial sediment and particulate nutrient exports following large tropical storms (Dhillon and Inamdar 2013, 2014; Inamdar et al. 2015). Stream runoff from a 12 ha forested watershed following tropical storm Irene in 2011 exported more than half the annual suspended sediment and organic carbon (OC) load in just $59 \mathrm{~h}$ (Dhillon and Inamdar 2013, 2014). A majority (87\%) of the total runoff organic carbon load was in particulate (POC) form (Dhillon and Inamdar 2013). The same storm exported 
one-third of the annual nitrogen $(\mathrm{N})$ export, primarily as particulate nitrogen (PN) (Inamdar et al. 2015). Here, we show that while large tropical storms could yield significant sediment and nutrient exports from watersheds, other coupled hydrologic and meteorological conditions could also produce similar or larger suspended sediment and nutrient yields. High-intensity rainfall events (February 16 and 24, 2016) following a sharp freeze-thaw episode in February 2016 resulted in some of the highest suspended sediment concentrations observed in our mid-Atlantic study watershed over the past 10 years of monitoring. This was also supported by high-frequency turbidity data measured at multiple, adjacent USGS stream flow stations. We propose that much of the sediment and nutrient export associated with the winter storms was likely due to erosion of streambank sediments and was driven by the coupled occurrence of freeze-thaw conditions and intense winter rainfall events. We hypothesize that such freeze-thaw cycles and intense winter rain events will likely increase with climate variability (Melillo 2014) and result in increased sediment and nutrient exports. This could potentially have detrimental consequences for water quality and aquatic health in watersheds with large supplies of streambank legacy sediments (e.g., Weitzman et al. 2014).

\section{Study site and methods}

Hydrologic and water quality data from multiple stream locations were used to compare and contrast the concentrations of suspended sediment, turbidity, and particulate nutrients among storms over the 2010-2016 time period. Suspended sediment and particulate nutrient data from small (12 and 79 ha) mid-Atlantic watersheds were compared for the 2016 winter freeze-thaw and rainfall events versus the tropical and other large storms. In addition, USGS turbidity data from larger adjacent watersheds were compared to evaluate the responses at a greater scale. To investigate the sources of the sediment associated with the winter 2016 storms, we evaluated previously collected (Johnson et al. submitted; Rowland et al. 2017) chemical fingerprint data for potential watershed sediment sources in a principal component mixing space.
Site description

The nested 12 and the 79 ha study watersheds (Fig. 1) have been intensively studied (Dhillon and Inamdar 2013, 2014; Inamdar et al. 2011, 2013, 2015) and are located in the Piedmont physiographic province in Cecil County, Maryland. The watersheds drain into the Big Elk Creek which subsequently empties into the Chesapeake Bay. The watersheds are predominantly forested (mean stand age of approximately 60 years), with pasture along the outer periphery. Dominant forest canopy species including Fagus grandifolia (American beech), Liriodendron tulipifera (yellow poplar), and Acer rubrum (red maple) with Symplocarpus foetidus (eastern skunk cabbage) prevalent in the valley-bottom wetlands. Bedrock formations consist of metamorphic gneiss and schist and soils are coarse loamy, mixed, mesic lithic inceptisols on slopes and oxyaquic inceptisols present in saturated valley bottoms. Elevations in the watershed range from 77 to $108 \mathrm{~m}$ with slope gradients ranging from $0.16^{\circ}$ to $24.5^{\circ}$ (mean $6.3^{\circ}$ ). The mean annual temperature is $13{ }^{\circ} \mathrm{C}$, the mean annual rainfall is $1205 \mathrm{~mm}$, and the mean annual snowfall is $447 \mathrm{~mm}$ (Maryland State Climatologist Office Data Page, 2016).

To investigate how the February 2016 storms affected the stream suspended sediment concentrations (SSC) at large drainage scales, we investigated the high-frequency data available for adjoining midAtlantic watersheds. While suspended sediment concentration (SSC) data were not available, turbidity data were available at 15-30 min frequency for the past 8-10 years at six USGS stream gaging stations in the adjoining watersheds (Fig. 2). Data from two of the stations is presented here-Brandywine Creek at Wilmington, DE (drainage area $813 \mathrm{~km}^{2}$; USGS-1 2017) and White Clay Creek at Strikersville, PA (153 km²; USGS-2 2017). Other stream locations displayed trends similar to these two selected watersheds and are reported in supplemental Figs. S3, S4, S5, S6 and S7. Since turbidity is considered a strong proxy for SSC (Gray and Gartner 2009; Rasmussen et al. 2009), we expected that these data would provide important insights on suspended sediment trends for the storm events.

Historic maps (Historic Map Works 2017) indicated that all three selected watersheds-Big Elk, White Clay, and Brandywine Creeks had numerous milldams along the length of the streams (every 
Fig. 1 The 12 ha (nested) and 79 ha experimental watersheds in the Piedmont region of Maryland (inset). The 79 ha watershed drains into the Big Elk Creek which eventually drains into the Chesapeake Bay
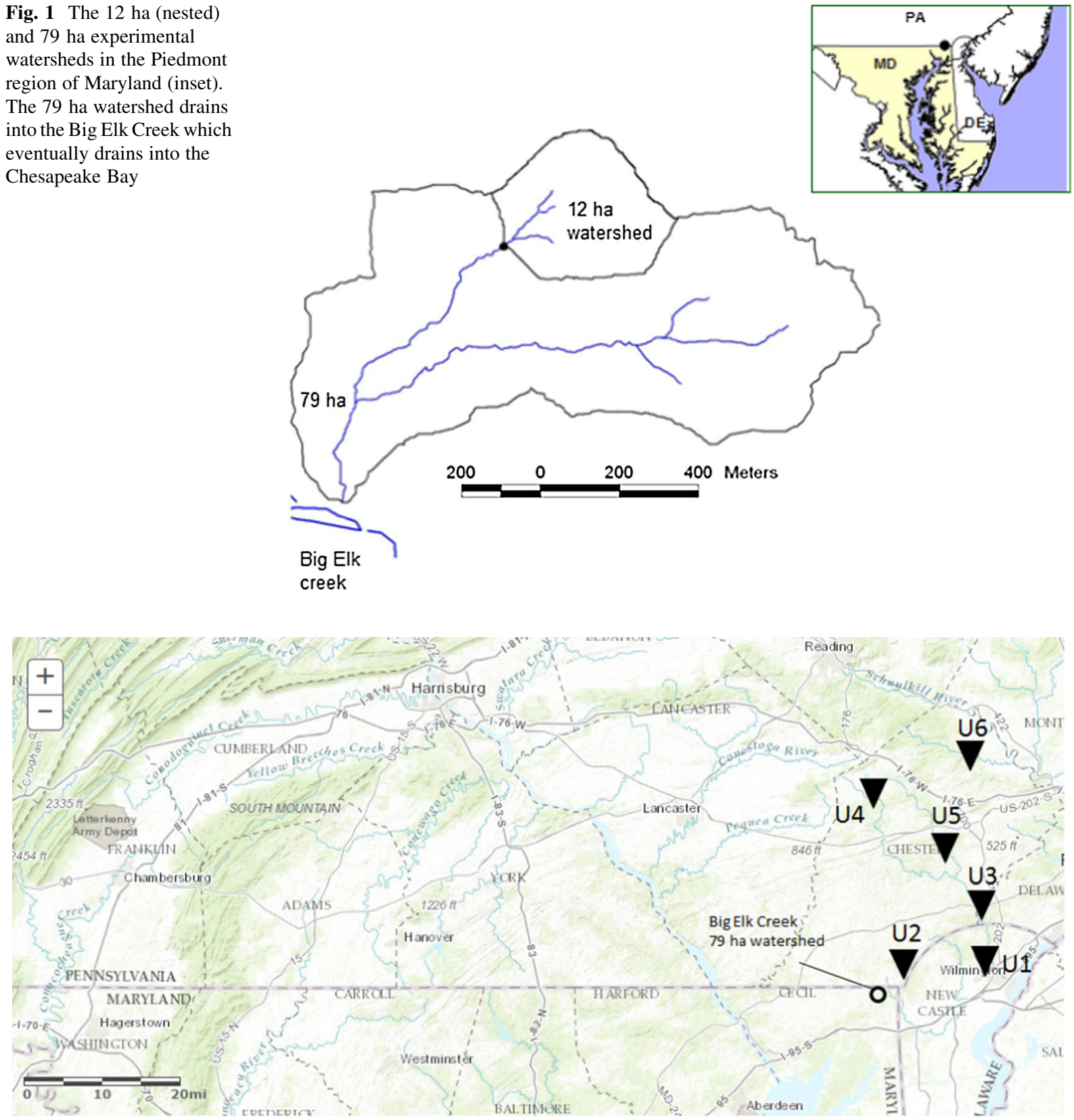

Fig. 2 Regional Map (source USGS) indicating the six selected USGS gage locations with high-frequency turbidity data. Locations are-U1-USGS 01481500 Brandywine Creek at Wilmington, DE; U2-USGS 01478245 White Clay Creek near Strickersville, PA; U3-USGS 01481000 Brandywine Creek at Chadds Ford, PA; U4-USGS 01480300 West Branch

2-4 km in many cases; e.g., see Fig. S1 in supplemental material)—alluding to large stores of legacy sediments in these watersheds. Streambank sediment depths along Big Elk creek and its tributaries ranged
Brandywine Creek near Honey Brook, PA; U5-USGS 01480870 East Branch Brandywine Creek below Downingtown, PA; and U6-USGS 01472157 French Creek near Phoenixville, PA. The location of the Big Elk Creek 79 ha subwatershed is also indicated by a circle on the map

from $<1 \mathrm{~m}$ to greater than $3 \mathrm{~m}$ near the dams (e.g., Fig. S2). 
Metrologic and hydrologic data

Hourly precipitation and air temperature data for the past 9 years was available from a weather station located in the Big Elk Creek watershed that drains southeastern Pennsylvania and northeastern Maryland (DEOS 2017). Hourly precipitation information allowed us to determine the intensities for the February 16 and 24, 2016 rain events and compare them against previous rainfall events (not possible with daily totals).

Hydrologic monitoring for the 12 and 79 ha Big Elk Creek subwatersheds have been described in detail in Dhillon and Inamdar (2013, 2014), Inamdar et al. (2015) and Rowland et al. (2017). Water level pressure transducers in a Parshall flume and calibrated rectangular culvert were used to measure stream discharge at the 12 and 79 ha locations, respectively. Discharge data for Brandywine and White Clay Creek were available from the online USGS sites.

Suspended sediment and particulate nutrient data

Suspended sediment, POC and PN sampling for the 12 and 79 ha Big Elk Creek subwatersheds have been described in detail in Dhillon and Inamdar (2013, 2014), Inamdar et al. (2015) and Rowland et al. (2017). Suspended sediments $(>0.7 \mu \mathrm{m})$ were collected using a combination of automated, stormtriggered, samplers (ISCO, Inc.) (Dhillon and Inamdar 2013, 2014) and instream composite samplers (Rowland et al. 2017). While ISCO sediment samples were collected for the February 24, 2016 event, only manual grab samples were available for the February 16, 2016 event since the ISCO tubing was frozen earlier in the February 16 event and failed to collect the sample. These data were compared against our previous large storm events, including tropical storms (Dhillon and Inamdar 2013, 2015; Inamdar et al. 2015) from these sites. Percent OC and $\mathrm{N}$ in suspended sediments were determined via coupled elemental analysis and isotope ratio mass spectrometry (EAIRMS) as described in Rowland et al. (2017). POC and PN concentrations were then determined by multiplying the percent values with suspended sediment concentrations (SSC). Sediment and particulate nutrient mass fluxes for storms were calculated by multiplying concentrations with streamflow discharge and summing those values over the selected time period (Dhillon and Inamdar 2013; Rowland et al. 2017).

To determine the sources of fluvial suspended sediment, we collected stream suspended sediments using instream composite samplers (that yielded sufficient sediments-more than those collected by ISCO samplers) and sampled a wide variety of potential watershed sources (described in Rowland et al. 2017). Watershed sources included —-forest floor litter and humus, upland A horizon, wetland soils (A horizon), stream bed, and stream bank $\mathrm{A}$ and $\mathrm{B}$ horizons (Rowland et al. 2017; Johnson et al. submitted). This source sampling was conducted across the 79 ha watershed with samples being collected from four separate portions of the watershed to account for spatial heterogeneity. The instream sampler consisted of a $10 \mathrm{~cm}$ diameter PVC pipes placed vertically in the stream with $1.5 \mathrm{~cm}$ holes on the upstream face. This allowed for sediment to enter and be captured/retained within the samplers. Sediment from these samplers were collected immediately after the end of the storm. Samples from multiple storms were collected as described in Rowland et al. (2017). Fluvial/stream sediments collected by instream samplers were sieved through $63 \mu \mathrm{m}$ sieve to characterize the fine sediments. All sediments were analyzed for $\% \mathrm{OC}$ and $\mathrm{N}$, stable isotopes of $\mathrm{C}$ and $\mathrm{N}\left({ }^{13} \mathrm{C}\right.$ and $\left.{ }^{15} \mathrm{~N}\right)$ using EAIRMS. In addition, solution extract of the sediment sources were also evaluated with fluorescence spectroscopy (see Johnson et al. submitted, for a complete description) to produce fluorescence metrics like $\%$ protein-, humic-, and fulvic-like contents (Inamdar et al. 2011). The aqueous extracted samples were also analyzed for total organic carbon (TOC) and total nitrogen (TN) on a Shimadzu TOC-L, TNM-L analyzer (Shimadzu, Colombia, MD). A principal component analysis (PCA) performed by Johnson et al. (submitted) on this data allowed for a comparison of storm-event suspended sediments against potential sources in the PCA mixing space. While the data for storms prior to 2016 were not available we compare the February 16 and 24, 2016 events against other events from 2016 to July 28 and 30, and August 21 (Johnson et al. submitted). The focus here was to identify the potential sediment sources for the February events (particularly the influence of streambank sediments) and how they were similar or different from other events of 2016. 
USGS turbidity data computations for storms

In addition to comparing peak turbidity concentrations for the storms, we also computed a "turbidity mass flux" index by multiplying the turbidity values with streamflow discharge for individual time steps and summing the product for the duration of the event and the year. This is analogous to determining the suspended sediment mass flux for storm events. An average annual turbidity mass flux was determined for the period of record (total mass flux divided by the number of years) and the event turbidity fluxes were then divided by this annual average to get the percent exports for the individual storm events. This allowed us to compare the events against each other in percent terms. We expect that these percent values would also be comparable to corresponding values for suspended sediment fluxes. Furthermore, to investigate the differences in temporal patterns of turbidity among events we developed concentration-discharge (CQ) (Evans and Davies 1998) plots for the events. CQ plots have been used to assess potential sources of sediments and or chemicals in runoff (Asselman 1999; Evans and Davies 1998; Gellis 2013).

\section{Results}

Metrologic and hydrologic attributes of 2016 winter versus other storms

Hourly precipitation data revealed that the rainfall events of February 16 and 24 were very intense (DEOS 2017). The total rainfall for the February 16 event was $32 \mathrm{~mm}$ over $10 \mathrm{~h}$ with $24 \mathrm{~mm}$ falling in $4 \mathrm{~h}$ (Fig. 3). In comparison, the event of February 24 produced $54 \mathrm{~mm}$ over $10 \mathrm{~h}$ with an intense rainfall burst of $21 \mathrm{~mm}$ in just $1 \mathrm{~h}$ (Fig. 3). If the $21 \mathrm{~mm} \mathrm{1-h}$ rain pulse is considered by itself, it ranks as the most intense hourly February rainfall for the available 9-year period (2008-2016) of record at this site. Notwithstanding the intensity, the rainfall occurrence itself was unprecedented, given that precipitation typically occurs as snow during this time of the year in this region. The winter of 2015-2016 was however, anything but normal, and was ranked as the warmest on record for the contiguous US (NOAA 2016). Air temperatures during the 2015-2016 winter varied wildly between warm and cold conditions. Prior to the rain events of February 16 and 24, the northeast and mid-Atlantic region of the US was subjected to a sharp southward plunge of the "polar vortex", a cold front from the North Pole (National Weather Service 2017). Average daily air temperatures were below freezing for 11 straight days prior to the rain event on February 16 (DEOS 2017; Fig. 3). Minimum air temperatures dropped to as low as $-15^{\circ} \mathrm{C}$ on February 14 (Fig. 3), but recovered quickly to above freezing prior to the rain events.

Rainfall totals for tropical storms Nicole (2010) and Irene and Lee (2011) (Table 1) were nearly two to three times greater than the February 2016 events. Not surprisingly, streamflows at the 12 and 79 ha drainage locations (7.3 and $5.8 \mathrm{~mm}$, respectively; Table 1) for the February 24 event were not high compared to those recorded for the tropical storms (Table 1). Similarly, streamflow discharge values at the USGS gage stations for the February winter events (Table 2) were lower
Fig. 3 Precipitation (mm) and air temperature $\left({ }^{\circ} \mathrm{C}\right)$ data for the month of February 2016 highlighting the freezing conditions prior to the arrival of the intense storms of February 16 and 24, 2016

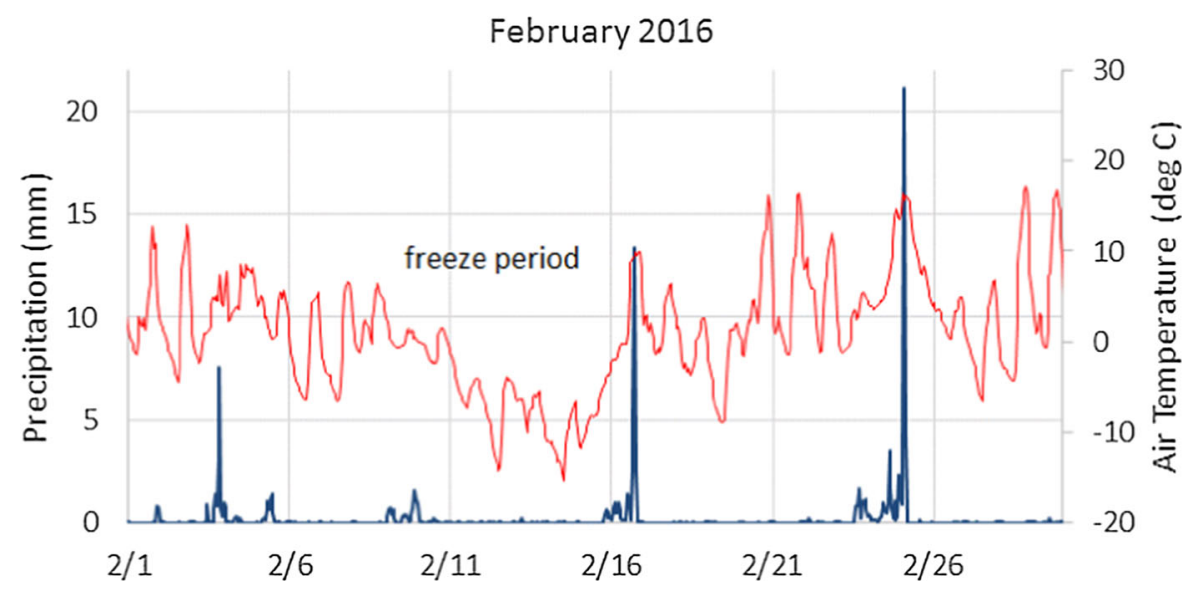


Table 1 Comparison of suspended sediment and POC concentrations and exports from the 12 and 79 ha watershed for the February 24, 2016 storm versus other large tropical storms (TS)

\begin{tabular}{|c|c|c|c|c|}
\hline \multirow[t]{2}{*}{ Description } & \multicolumn{4}{|c|}{ Event date (month/day/year) } \\
\hline & $2 / 24 / 2016$ & 8/27/2011 (TS Irene) & 9/6/2011 (TS Lee) & 9/30/2010 (TS Nicole) \\
\hline Rainfall (mm) & 54 & 155 & 102 & 151 \\
\hline \multicolumn{5}{|l|}{12 ha watershed } \\
\hline Streamflow (mm) & 7.3 & 32.7 & 16.5 & 13.5 \\
\hline Peak SSC (mg/L) & 5171 & 3874 & 2883 & 2330 \\
\hline Mass export SSC (kg/ha) & 265 & 730 & 468 & 108 \\
\hline Peak POC (mg/L) & 253 & 112 & 11.3 & 190 \\
\hline Mass export POC (kg/ha) & 9.5 & 21.2 & 1.2 & 9 \\
\hline Peak PN (mg/L) & 15.8 & 8.79 & 0.96 & 17.4 \\
\hline Mass export PN (kg/ha) & 0.77 & 1.76 & 0.1 & 0.82 \\
\hline \multicolumn{5}{|l|}{79 ha watershed $^{\mathrm{a}}$} \\
\hline Streamflow (mm) & 5.8 & NA & NA & NA \\
\hline Peak SSC (mg/L) & 35,715 & NA & NA & NA \\
\hline Mass export SSC (kg/ha) & 960 & NA & NA & NA \\
\hline Peak POC (mg/L) & 1214 & NA & NA & NA \\
\hline Mass export POC (kg/ha) & 32.6 & NA & NA & NA \\
\hline Peak PN (mg/L) & 62.5 & NA & NA & NA \\
\hline Mass export PN (kg/ha) & 1.68 & NA & NA & NA \\
\hline
\end{tabular}

${ }^{\mathrm{a}}$ Data was lost because of flooding at the 79 ha location for the other large storms

Table 2 Comparison of turbidity concentrations and percent mass exports from the Brandywine and White Clay creeks for multiple storm events

\begin{tabular}{|c|c|c|c|c|c|c|c|}
\hline \multirow[t]{2}{*}{ Description } & \multicolumn{7}{|c|}{ Event date (month/day/year) } \\
\hline & $2 / 16 / 16$ & $2 / 24 / 16$ & $5 / 1 / 14$ & $\begin{array}{l}\text { 10/30/12 TS } \\
\text { Sandy }^{\mathrm{a}}\end{array}$ & $\begin{array}{l}\text { 8/27/11 TS } \\
\text { Irene }\end{array}$ & $\begin{array}{l}\text { 9/6/11 TS } \\
\text { Lee }\end{array}$ & $\begin{array}{l}\text { 9/30/10 TS } \\
\text { Nicole }\end{array}$ \\
\hline \multicolumn{8}{|c|}{ Brandywine Creek at Wilmington, DE (drainage $813 \mathrm{~km}^{2}$ ) } \\
\hline Event duration (h) & 69.2 & 82.5 & 172 & 120.2 & 103.5 & 143 & 85.7 \\
\hline Discharge (mm) & 14 & 29 & 88 & 37 & 57 & 55 & 39 \\
\hline Peak turbidity (FNU) & 430 & 600 & 330 & 164 & 255 & 202 & 296 \\
\hline Turbidity mass ${ }^{\mathrm{b}}(\%)$ & 16 & 50 & 70 & 16 & 35 & 21 & 30 \\
\hline \multicolumn{8}{|c|}{ White clay Creek at Strickersville, PA (drainage 153 km²) $^{2}$} \\
\hline Event duration (h) & 56.5 & 52 & 72 & 58.7 & & & \\
\hline Discharge (mm) & 15 & 24 & 67 & 36 & NA & NA & NA \\
\hline Peak turbidity (FNU) & 1350 & 1470 & 1080 & 400 & NA & NA & NA \\
\hline Turbidity mass ${ }^{\mathrm{b}}(\%)$ & 19 & 52 & 84 & 22 & NA & NA & NA \\
\hline
\end{tabular}

The February 16 and 24 freeze-thaw storms are shaded to differentiate them from the other storms

${ }^{\mathrm{a}} T S$ tropical storm

${ }^{\mathrm{b}}$ Percent mass exports were expressed as a percentage of the average annual turbidity mass (averaged over the period of record) 
than those recorded for tropical storms and the large spring event from 2014.

Stream sediment and nutrient fluxes for storm events

Peak SSC for the February 24 event at the 12 ha outlet $(5171 \mathrm{mg} / \mathrm{L})$ was nearly twice that recorded for the tropical storms at the same location (Table 1). The suspended sediment mass flux at the 12 ha outlet for the February 24 storm ( $265 \mathrm{~kg} / \mathrm{ha}$ ) was much less than that for tropical storm Irene $(730 \mathrm{~kg} / \mathrm{ha})$, half of that for Lee $(468 \mathrm{~kg} / \mathrm{ha})$, but twice that for Nicole $(108 \mathrm{~kg} /$ ha). The sediment flux for this event then increased sharply to $960 \mathrm{~kg} / \mathrm{ha}$ at the downstream 79 ha drainage location (Table 1). Peak SSC at the 79 ha site $(35,715 \mathrm{mg} / \mathrm{L})$ was exceptional and an order of magnitude greater than that recorded at the 12 ha site for all the storms (Table 1). While ISCO data were not available for the February 16 event (frozen tubing), we did collect two grab samples of stream runoff during the time of the photo in Fig. $4 \mathrm{a}$ and the average SSC was $4617 \mathrm{mg} / \mathrm{L}$; a fairly high concentration, but lower than concentrations recorded for the subsequent February 24, 2016 event. Similar to SSC, POC and PN concentrations and exports were also very high for the February 24 event (Table 1) indicating substantial exports of particulate nutrients with such events. Despite the seasonal differences in POC and PN concentration/content in sediments across the storms, POC and PN exports for the February 24 event were comparable to those for Nicole and exceeded those recorded for tropical storm Lee. Our visual observations in upland and near-stream areas of the watersheds (12 and 79 ha) on February 16 at the time of peak flow, did not reveal any significant upland or hillslope erosion. On the contrary, hillslopes and nearstream areas were still covered with snow (as is apparent in Fig. 4a) overlying the thick forest litter and erosion and sediment transport was only visually apparent in first-order and higher streams .

\section{Turbidity values and "mass flux" for USGS} streams

Turbidity values and mass flux data in Fig. 5 (Brandywine Creek at Wilmington, DE) and Table 2 further underscore the significance of the February 2016 storms at large drainage scales (see also Figs. S3, S4,
S5, S6 and S7 for other USGS sites). The peak turbidity concentration in Brandywine Creek for the February 24 event (600 FNU; Table 2) was the highest measured over the available 9-year record including multiple large and tropical storms. Peak turbidity for the February 24 event exceeded the value of $\sim 255$ FNU (Table 2) recorded during tropical storm Irene and greater than 330 FNU measured for the large spring (May 1) storm of 2014. Turbidity mass flux for Brandywine Creek for the February 24 storm indicated that in just $82.5 \mathrm{~h}(\sim 1 \%$ of the year) it contributed to $50 \%$ of the average annual turbidity flux (Table 2). This \% flux was greater than all four of the previous large tropical storms [e.g., Nicole (September 30, 2010), Irene (August 27, 2011), Lee (September 6, 2011), and Sandy (October 30, 2012)] and second only to that for the large May 1, 2014 event (70\%; Table 2). A similar pattern in turbidity concentrations and mass flux was observed for the White Clay Creek (Table 2) USGS stream. White Clay Creek peak turbidity values for the February 24 event were even greater than Brandywine Creek at 1470 FNU and contributed to $52 \%$ of the annual flux (Table 2). The large values and fluxes of turbidity occurred in spite of lower stream flows for the February events compared to the other large storm events (Table 2).

The turbidity CQ plots for the storms for Brandywine Creek (Fig. 6) also highlight important differences among the events. Turbidity concentrations for the tropical storms (Irene, Lee, and Sandy) and the large event of May 1, 2014 generally peaked early on the rising limb of the stream hydrograph (Fig. 6, top panels) resulting in clockwise hysteresis and CQ loops that were shifted to the right (Fig. 6, bottom panels). In contrast, both the February events produced turbidity concentrations that closely followed the temporal pattern of the discharge values and had turbidity peaks just before the discharge peaks. While this maintained the clockwise hysteresis for the events, the shape of the loops was more linear and shifted to the left (Fig. 6). Turbidity or suspended sediment peaks early on the rising limb of the discharge hydrograph are generally attributed to upland erosion and sediment transport with infiltration-excess or saturation excess overland flow (Gellis 2013 and references therein). In comparison, sediment concentrations that closely follow the streamflow discharge (and produce a linear loop) suggest sediment supply from near-stream sources and mobilization of sediments in concert with 
(a)

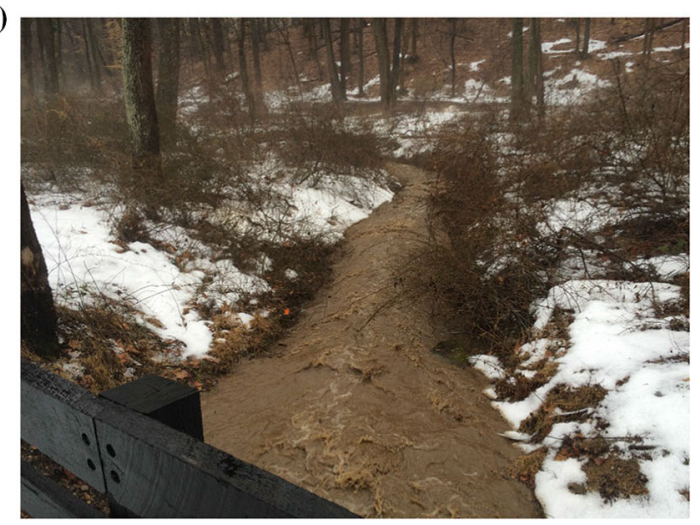

(b)

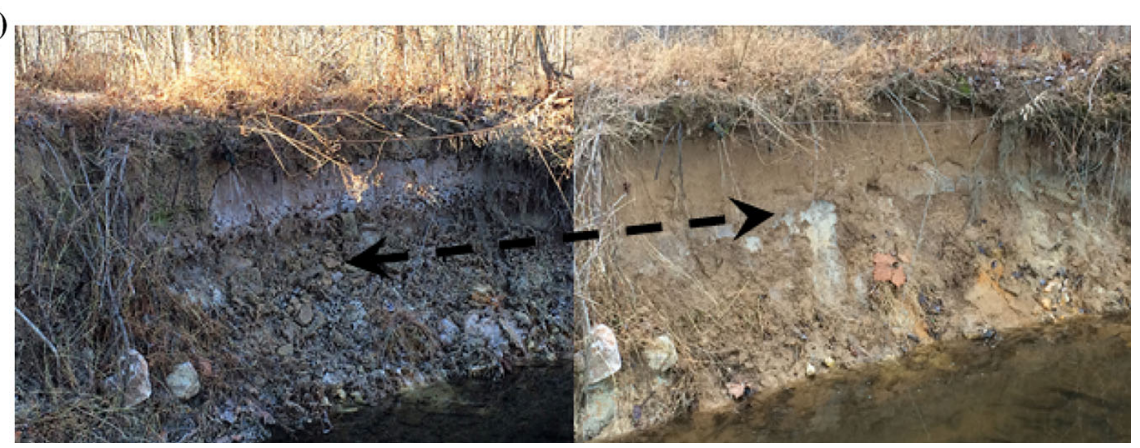

Fig. 4 a High suspended sediment concentrations $(4617 \mathrm{mg} / \mathrm{L}$ at the time of the picture) at the outlet of the 79 ha catchment (second order stream) during peak stream flow $(\sim 12: 30 \mathrm{pm})$ on February 16, 2016. Note that adjoining uplands and hillslope are still covered with snow and upland erosion is minimal. b Freeze-thaw action results in loss of cohesive strength and

rising and falling stream water levels - such as erosion and transport of streambanks and bed (Gellis 2013).

Comparison of stream sediment against potential watershed sediment sources

The PCA mixing space (Fig. 7) revealed a pronounced separation in watershed sediment sources. A detailed description of the parameters used and their contributions to the principal components is provided in Johnson et al. (submitted). The $\%$ fulvic-like metric was particularly valuable in separating out the streambank sediment source (Johnson et al. submitted). In contrast to the end-members, the stream sediments for storms (February 16 and 24, July 28 and 30, and August 21, 2016) were primarily clustered in the vicinity of the streambank B, streambed, and wetland sources. Sediments from the February 16 event were closest to the streambank B end-member indicating a detachment and slumping of legacy sediments "drool" from streambanks (photo of Big Elk creek tributary in Maryland after a severe freeze-thaw event in December, 2016); and (right) the same bank surface a few days later-after runoff from a storm event had washed away the loose sediment

strong influence of this source on fluvial sediments transported during this storm. Sediments for the February 24 and July 30 events were shifted downwards in the mixing space and towards the stream bed sediment source. Sediments for the July 28 and August 21 were shifted further to the right indicating an increasing influence of either the wetland sediment source or other sources positioned further to the right.

\section{Discussion}

Role of freeze-thaw processes in sediment and nutrient erosion/production

The role of freeze thaw processes in "loosening" soils and sediments and making them vulnerable/available to erosion, particularly on stream banks, is well recognized (e.g., Ferrick and Gatto 2005; Lawler 

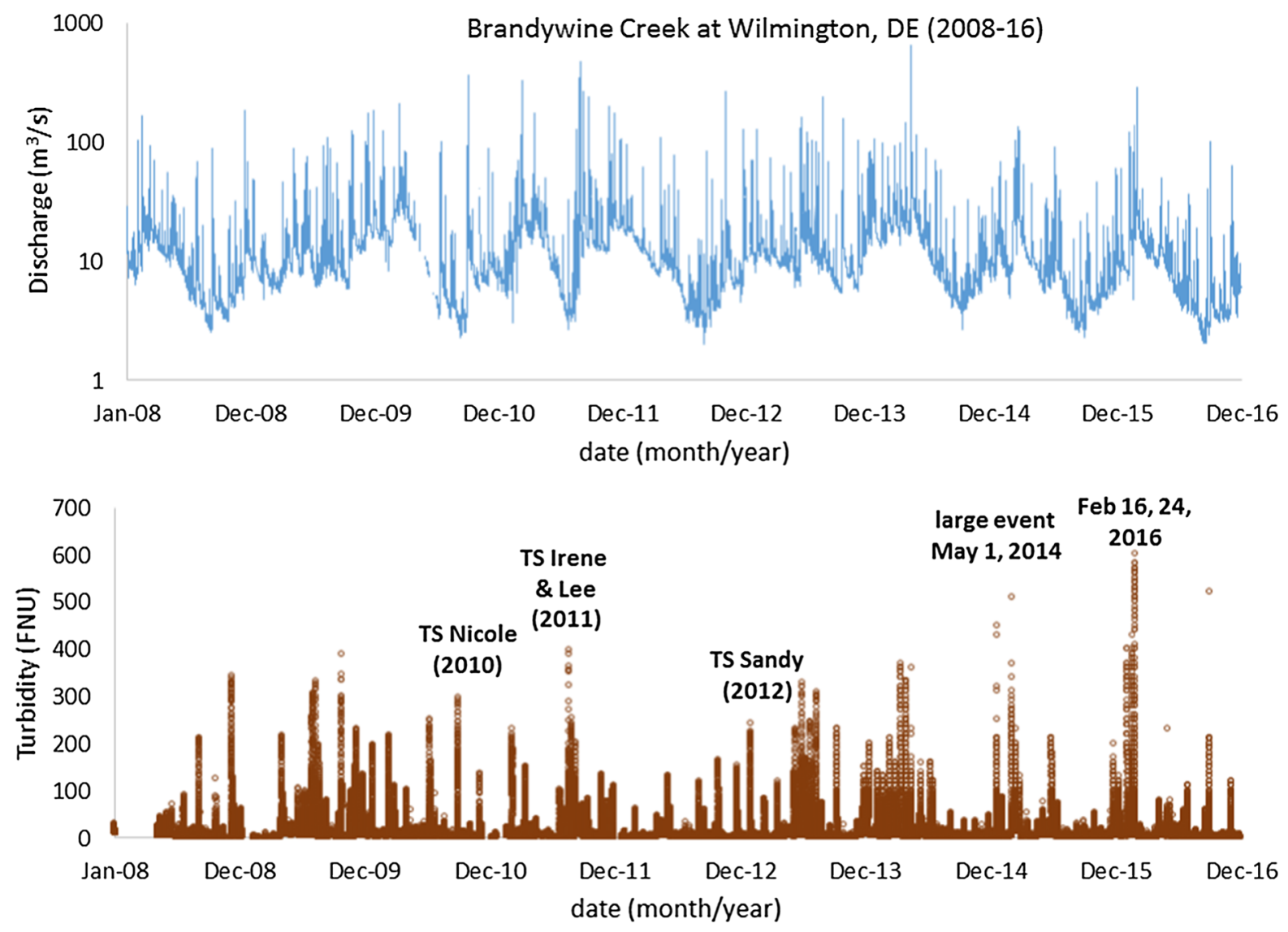

Fig. 5 Time series of streamflow discharge $\left(\mathrm{m}^{3} / \mathrm{s}\right.$; blue line) and turbidity concentrations (FNU; brown circles) recorded for Brandywine Creek at Wilmington, DE over a period of 9 years

1993a, b; Wolman 1959). Freeze-thaw cycles cause bank sediments to lose their cohesive strength with subsequent detachment and slumping/collapse at the base of the streambank (Merritts et al. 2013; Wolman 1959; Wynn 2006). Freeze-thaw erosion (Couper 2003; Lawler 1993a, b; Merritts et al. 2011, 2013; Wolman 1959) along with fluvial erosion with large storms (Gellis et al. 2017) and mass wasting of stream banks (Fox et al. 2016) have been hypothesized as some of the important mechanisms for erosion of stream-bank sediments. Wynn and Mostaghimi (2006) have also shown that the number of freeze-thaw cycles has a cumulative destabilizing effect on streambank sediments. Since fine sediments (silt and clay) are particularly susceptible to effects of freeze thaw (Couper 2003; Wynn and Mostaghimi 2006), fine-grained millpond legacy sediments along the and at a frequency of $15 \mathrm{~min}$. Maximum turbidity concentrations (600 FNU) were recorded for the event of February 24, 2016

streambanks, as in case of our study sites, would especially be vulnerable to this erosion.

Large contributions of streambank sediments to suspended sediment exports have previously been reported for Piedmont watersheds (Gellis et al. 2009, 2017; Voli et al. 2013). Gellis et al. (2017) reported that eroding streambanks accounted for as much as $70 \%$ of the suspended sediment fluvial exports from tropical storms Lee and Sandy. Their work was conducted in a suburban and urban, fifth order, drainage basin (area $14.2 \mathrm{~km}^{2}$ ) near Baltimore, Maryland that contained legacy sediments. While the streambank sediment contributions were high, they were not able to conclusively link freeze-thaw activity to streambank erosion. Gellis et al. (2017) monitored freeze-thaw days between bank erosion measurements performed once a year or after the large storms using erosion pins, but also recognized that daily or 
Fig. 6 (Top) Hydrographs (blue line) and suspended sediment concentrations (brown circles) for storms of February 24, 2016 and May 1, 2014; and (bottom) concentration-discharge (CQ) loops for the five large storms. The February storms (16 and 24, 2016) show linear loops while the storms from May 1, 2014, TS Irene Lee (September 6, 2011) are shifted to the right (August 27, 2011), and TS
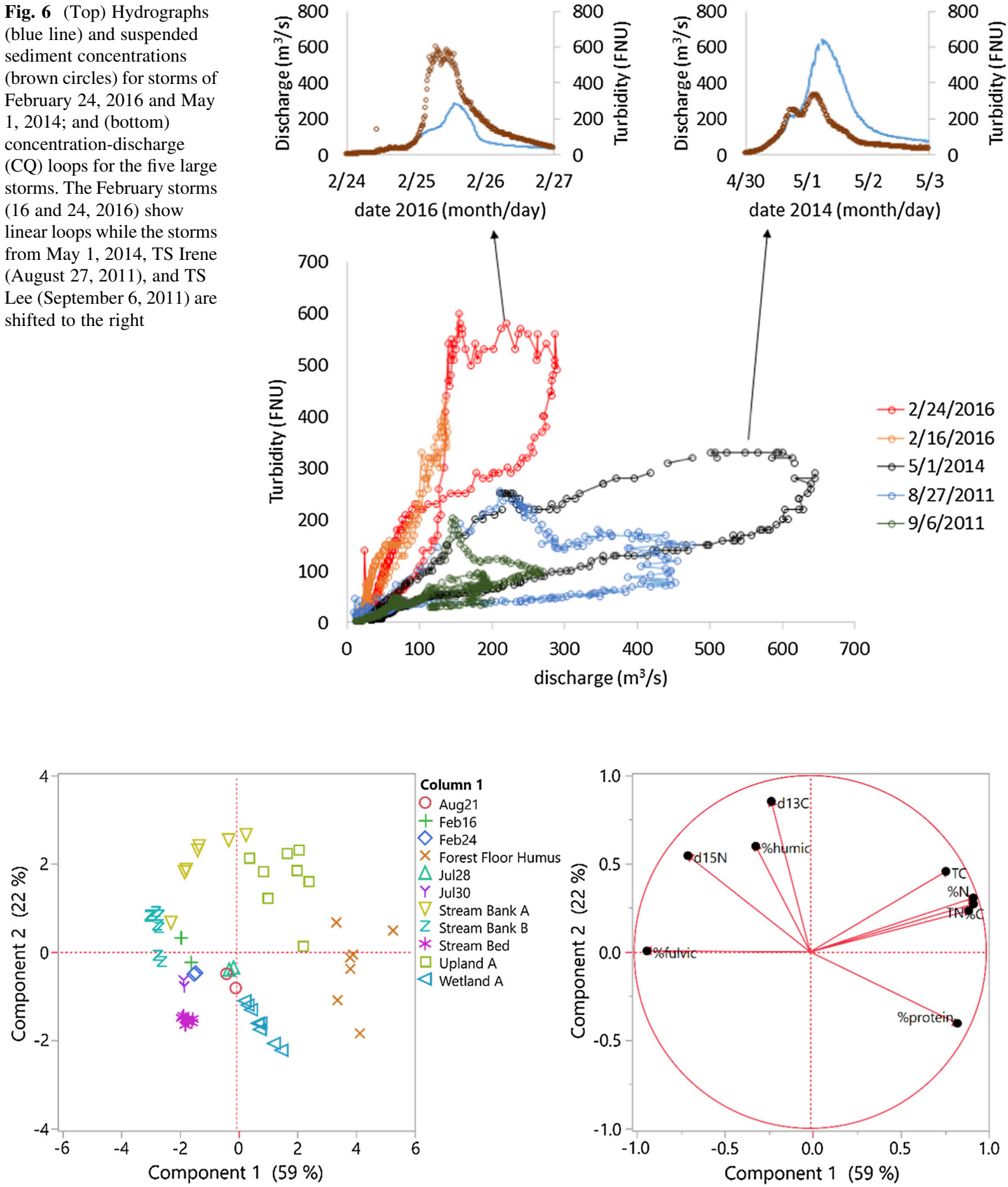

Fig. 7 Principal component mixing space highlighting the distribution of potential watershed sediment sources and fine grained $(<63 \mu \mathrm{m})$ fluvial suspended sediments associated with storms (February 16 and 24, July 28 and 30, and August 21, 2016). Parameters used in the PCA included-stable isotopes of
$\mathrm{C}\left({ }^{13} \mathrm{C}\right)$ and $\mathrm{N}\left({ }^{15} \mathrm{~N}\right), \% \mathrm{TC}$ and $\mathrm{TN}$ of sediments, DOC and TN concentrations of sediment extracts and fluorescence metrics (\% protein-, humic- and fulvic-like) for sediment extracts (modified from Johnson et al.) 
weekly measurements of bank erosion were likely needed to thoroughly assess the effects of freeze-thaw on bank erosion. Other investigators using infrequent, low frequency, LIDAR scans for bank erosion measurements reached a similar conclusion (e.g., Lyons et al. 2015; Merritts et al. 2013).

Our observations of sediment fingerprinting (Fig. 7), high-frequency turbidity CQ loops (5), and visual observations of freeze-thaw "drool" on streambanks prior to rain events and which was washed off (absent) post the rain events (Fig. 4b), taken together, suggest that streambank and bed sediments were important contributors to the sediment and particulate nutrient loads observed for the intense February events. The influence of streambank sediments as a potential source for fluvial sediments was particularly notable for the first of the two February events (February 16, Fig. 7). This should be expected given the first flush of the exposed "drool" sediments (Fig. 4b) by incident rainfall into the stream. Unfortunately, data were not available for the tropical storms (Nicole, Irene and Lee) to make sediment source evaluations and comparisons against the February events. We recognize here that in addition to streambanks, bed sediments could represent a large reservoir of sediments and nutrients in the fluvial network and could be important contributor to sediment loads during large storms. Bed sediments likely represent an integrated signature of all potential sources with streambank contributions to this pool varying with freeze-thaw and other bank erosive mechanisms (more on this in the next section).

While we recognize the limitations in using turbidity as a surrogate for suspended sediment concentrations, our results show that high-frequency turbidity data could be an important tool for recording the erosion from episodic freeze-thaw events and could be a sensitive measure to monitor such events. Logistical challenges associated with cold conditions and frozen streams could preclude the use of other devices such as automated water samplers (as we learned through experience with the February 16 storm). We also emphasize that while we computed "turbidity fluxes" from the various events (Table 2) they were not used as absolute measures of suspended sediment, but rather as an estimate of the relative fluxes of sediment load that could be expected from the events (note that storm event turbidity fluxes were normalized by annual turbidity totals).
Beyond the physical process of erosion and destabilization of streambank sediments, freeze-thaw cycles could also alter the chemical mechanisms of sorption-desorption and/or mineralization and immobilization of nutrients in sediments (e.g., Henry 2007) and thus affect nutrient release from sediments and eventual exports. Numerous studies have reported release of inorganic and organic forms of phosphorus and nitrogen via desorption and mineralization from sediments subject to freeze-thaw cycles (e.g., Freppaz et al. 2014; Fitzhugh et al. 2001; Henry 2007; Vaz et al. 1994; Wang and Liu 2017). It should also be noted that freeze-thaw action typically results in smaller/finer aggregates (Edwards 2013) from bank sediments, occasionally referred to as "drool" (Fig. 4b), as opposed to larger "chunks" of sediment (Wegmann et al. 2013) that may be generated by fluvial erosion and mass wasting. One would expect more nutrient leaching and microbial processing of fine aggregates (because of larger exposed surface area) as opposed to larger "chunks" of sediments in the stream.

Coupled versus individual extreme events

for sediment and nutrient exports

Our results show that while individual tropical (e.g., Irene, Table 1) and other large storms (e.g., May 1, 2014 event; Table 2) indeed produced large sediment and nutrient fluxes, there could also be other coupled, "less extreme" conditions and events, that could produce similar or larger sediment and nutrient concentrations and exports. We hypothesize that the sharp freeze-thaw, "polar vortex" driven event that preceded the February 16 rainfall likely "primed" the streambank sediments (Fig. 4b) for erosion by loosening and detaching the bank sediments. The intense February rainfall events, particularly the one on 24th (the most intense February rainfall event on record 2008-2016), then delivered the decisive second of the "one-two punch" that resulted in the high sediment and nutrient exports for the February events. Freezethaw cycles have occurred in previous years, but the warmest winter (2016) on record for the contiguous US (NOAA 2016), likely amplified the effects of freeze-thaw and importantly, allowed for precipitation to occur as rain rather than snow in the month of February. 
Coupled events resulting in large/extreme sediment and nutrient fluxes have been reported for other types of conditions and locations. Yellen et al. (2016) found that tropical storm Irene yielded the highest sediment load on record in the Connecticut River watershed despite not having the highest streamflow. They attributed the response to wet antecedent conditions prior to the Irene rainfall. Antecedent 30-day precipitation preceding Irene fell in the 95th percentile of all days for the past 100 years. Similarly forest fires preceding floods have been found to produce exceptional exports and concentrations of sediments and nutrients from watersheds (e.g., Dahm et al. 2015; Murphy et al. 2015). Peak concentrations of totals suspended solids, dissolved organic carbon and nitrate were $120,000 \mathrm{mg} \mathrm{TSS} \mathrm{L}{ }^{-1}, 12 \mathrm{mg} \mathrm{NO}^{-} \mathrm{L}^{-1}$, and $71 \mathrm{mg} \mathrm{DOC} \mathrm{L}^{-1}$, respectively, and were 10-31 times greater than those in unburned streams in the 6330-ha Fourmile Creek watershed near Boulder, Colorado (Murphy et al. 2015).

The influence of freeze-thaw cycles and intense winter rain events on sediment and particulate nutrient exports is especially of concern considering the large reservoir of valley-bottom legacy sediments in eastern US Piedmont watersheds (Merritts et al. 2011; Walter and Merritts 2008; Wegmann et al. 2012). Streambank legacy sediments represent a large potential supply of near-stream sediments and freeze-thaw activity represents a key destabilizing mechanism that can increase the "availability" of this large sediment reservoir (Couper 2003; Lawler 1993a). Intense winter rain events and associated runoff provides the transport mechanism that can mobilize this "available" sediment supply and flush it through the fluvial network. This supply-transport scenario could be further amplified by climate variability (e.g., conceptual one-two punch model in Fig. 8). Intensification of storm events (Melillo 2014) and the instability of the polar vortex (e.g., Zhang et al. 2016) could result in increased variability in winter air temperatures and soil/sediment freeze thaw cycles. We hypothesize (Fig. 8) that increased frequency of freeze-thaw cycles will increase the erosion of streambank legacy sediments and their storage in bed sediments. The intense winter rainfall events would then transport the larger reservoir of sediment and nutrients through the fluvial network.
Broader water quality and management implications

This study shows that freeze-thaw events and intense winter rainfall events could yield substantial sediment and sediment-associated nutrients. This could further exacerbate the problem of nutrient enrichment and eutrophication in sensitive and vulnerable aquatic ecosystems such as the Chesapeake Bay (Dennison et al. 2012). In addition to the amount of sediment and nutrient input, the timing of the winter events, ahead of the biologically-sensitive spring spawning season, could also be of concern. Large inputs of sediments early in the year could bury spawning beds, affect reproductive stages of aquatic habitat, and influence early season growth of aquatic grasses (Dennison et al. 2012; Orth et al. 2010). Early spring or winter season storms, as opposed to late season tropical storms, have been observed to have a greater negative impact on the aquatic life cycles in the Chesapeake Bay (Dennison et al. 2012).

Watershed management practices to mitigate nonpoint source pollution (NPS) are typically geared towards upland management (e.g., conservation tillage, cover crops, etc.) as opposed to management and mitigation of stream-bank legacy sediments (Fox et al. 2016; Merritts et al. 2011; Sharpley et al. 2013). Given the relatively recent recognition of stream-bank legacy sediments as sediment sources, there is considerable uncertainty about the potential impact they may have on sensitive and vulnerable downstream aquatic ecosystems such as the Chesapeake Bay (Brainard 2011; Fincham 2011). There is considerable concern among regulatory and water management agencies (STAC, Chesapeake Bay Program 2017) that erosion of these near-stream legacy sediments could undermine the gains made over the past few decades in controlling upland NPS sources through on-farm best management practices (BMPs; Liu et al. 2017; Rittenburg et al. 2015). Another factor that could further aggravate the situation is the increasing urbanization of watersheds in the mid-Atlantic and the Chesapeake Bay watershed. Urbanization increases stream flow variability (lower base flows and higher peak flows) resulting in increased scouring and incised and exposed streambanks (Paul and Meyer 2001; Voli et al. 2013). If winter climate variability and intense rain events increase the destabilization and scouring of streambank legacy sediments, it could 
Fig. 8 Conceptual model illustrating how climate variability could impact the one-two punch of freezethaw cycles and intense winter rain events and influence streambank exports of sediment and nutrients from fluvial systems. Legacy sediments in mid-Atlantic valley bottoms represent the large supply while climate variability would enhance the transport

\begin{tabular}{|c|c|c|}
\hline & Low & High \\
\hline $\begin{array}{l}\text { SUPPLY: } \\
\text { Freeze thaw } \\
\text { cycles \& } \\
\text { sediment } \\
\text { supply } \\
\text { /mobilization }\end{array}$ & $\begin{array}{l}\text { Soil/air temperature } \\
\text { Consistent temperatures, low } \\
\text { number of freeze-thaw cycles } \\
\text { Small amount of freeze-thaw } \\
\text { driven bank erosion; low } \\
\text { accumulation \& storage in } \\
\text { stream bed }\end{array}$ & $\begin{array}{l}\text { Increased temperature } \\
\text { variability, greater number of } \\
\text { freeze-thaw cycles } \\
\text { Freeze-thaw cycles destabilize } \\
\text { banks causing erosion/"drool"; } \\
\text { bank sediment falls and } \\
\text { accumulates on the stream bed } \\
\text { increasing bed sediment depth }\end{array}$ \\
\hline $\begin{array}{l}\text { TRANSPORT: } \\
\text { Winter } \\
\text { rainfall } \\
\text { events and } \\
\text { sediment \& } \\
\text { nutrient } \\
\text { transport }\end{array}$ & $\begin{array}{l}\text { Winter precipitation primarily } \\
\text { as snow or occasional low- } \\
\text { intensity rainfall } \\
\text { Low streamflow and low } \\
\text { amounts of fluvialerosion and } \\
\text { sediment transport }\end{array}$ & $\begin{array}{l}\text { Increased frequency of high } \\
\text { intensity winter rain events } \\
\text { Increased stream flows and } \\
\text { increased fluvial erosion and } \\
\text { transport of bed and bank } \\
\text { sediments. }\end{array}$ \\
\hline
\end{tabular}

influence how best future BMPs are located and prioritized in watersheds in the Chesapeake Bay region and elsewhere.

\section{Conclusions}

This study revealed that intense winter rain storms coupled with freeze-thaw conditions could contribute a significant proportion of the annual watershed sediment and particulate nutrient yield in a fraction of the time. A large fraction of this sediment loading could come from streambank and bed sediments. Neither of these aspects (drivers of erosion and sediment sources) are accounted for rigorously in existing watershed numeric models. For example, in the Chesapeake Bay watershed model, sediment and nutrient loadings are based primarily on estimates of upland erosion from different types of land use and do not account for scouring of streambank sediments or 
freeze-thaw erosion processes (Chesapeake Bay Program 2017). Given the magnitude of the sediment exports and the expected climate variability, greater attention needs to be paid to monitoring and understanding these winter rain events. High-frequency instream sensors combined with modern sediment fingerprinting and traditional monitoring techniques need to be employed to better understand the effects of freeze-thaw activity on watershed sediment and nutrient budgets.

Acknowledgements This study was Funded through Grants NSF EPSCoR RII Track-1 OIA-1301765, IIA 1330446 and USDA-NIFA 2015-67020-23585. We thank the Fair Hill Natural Resource Management Area for providing access to the study site. We also thank USGS for the valuable highfrequency turbidity data being collected at their sites and available freely. We are grateful to the editors and reviewers for their constructive comments. Data used in this work is available on request from the corresponding author.

Open Access This article is distributed under the terms of the Creative Commons Attribution 4.0 International License (http:// creativecommons.org/licenses/by/4.0/), which permits unrestricted use, distribution, and reproduction in any medium, provided you give appropriate credit to the original author(s) and the source, provide a link to the Creative Commons license, and indicate if changes were made.

\section{References}

Asselman N (1999) Suspended sediment dynamics in a large drainage basin: the River Rhine. Hydrol Process 13:1437-1450

Banks WSL, Gellis AC, Noe G (2010) Sources of fine-grained suspended sediment in Mill Stream Branch Watershed, Corsica River Basin, a tributary to the Chesapeake Bay, Maryland, 2009. In: Proceedings, 2nd Joint Federal Interagency Conference, Las Vegas, NV, June 27 July 1, 2010. CD-ROM ISBN 978-0-0779007-3-2, 6B, pp 1-12

Brainard J (2011) Bay sediment? In dams, sediment and the Bay. Chesapeake quarterly, Maryland Sea Grant College, vol 10, no. 4. University of Maryland, College Park, MD

Chesapeake Bay Program (2017) Phase 5.3 Watershed model. Web page-http://www.chesapeakebay.net/about/ programs/modeling/53/. Accessed 28 Mar 2017

Couper P (2003) Effects of silt-clay content on the susceptibility of river banks to subaerial erosion. Geomorphology 56:95-108

Dahm CN et al (2015) Extreme water quality degradation following a catastrophic forest fire. Freshw Biol 60:2584-2599

Dennison WC, Saxby T, Walsh BM (2012) Responding to major storm impacts: Chesapeake Bay and the Delmarva Coastal
Bays. University of Maryland Center for Environmental Science (ian.umces.edu)

DEOS (Delaware Environmental Observing System) (2017) Data access portal-http://deos.udel.edu/data/. Accessed 26 Mar 2017

Dhillon GS, Inamdar S (2013) Extreme storms and changes in particulate and dissolved organic carbon in runoff: entering uncharted waters? Geophys Res Lett 40:1322-1327. https://doi.org/10.1002/grl.50306

Dhillon GS, Inamdar S (2014) Storm event patterns of particulate organic carbon for large storms and differences with dissolved organic carbon. Biogeochemistry 118(1):61-81. https://doi.org/10.1007/s10533-013-9905-6

Donovan M, Miller A, Baker M, Gellis A (2015) Sediment contributions from floodplains and legacy sediments to Piedmont streams of Baltimore County, Maryland. Geomorphology 235:88-105

Edwards LM (2013) The effects of soil freezethaw on soil aggregate breakdown and concomitant sediment flow in Prince Edward Island: A review. Can J Soil Sci 93:459472

Evans C, Davies TD (1998) Causes of concentration/discharge hysteresis and its potential as a tool for the analysis of episode hydrochemistry. Water Resour Res 34:129-137

Ferrick MG, Gatto LW (2005) Quantifying the effect of a freeze-thaw cycle on soil erosion: laboratory experiments. Earth Surf Process Landf 30:1305-1326

Fincham M (2011) Those damned old rivers. In: Dams, sediment and the Bay. Chesapeake quarterly, Maryland Sea Grant College, vol 10, no. 4. University of Maryland, College Park, MD

Fitzhugh RD, Driscoll CT, Groffman PM, Tierney GL, Fahey TJ, Hardy JP (2001) Effects of soil freezing, disturbance on soil solution nitrogen, phosphorus, and carbon chemistry in a northern hardwood ecosystem. Biogeochemistry 56:215-238

Fox GA, Purvis RA, Penn CJ (2016) Streambanks: a net source of sediment and phosphorus to streams. J Environ Manag 181:602-614

Freppaz M, Williams BL, Edwards AC, Scalenghe R, Zanoni E (2014) Simulating soil freeze/thaw cycles typical of winter alpine conditions: implications for $\mathrm{N}$ and $\mathrm{P}$ availability. Appl Soil Ecol 35:247-255

Garner G, Van Loon AF, Prudhomme C, Hannah DM (2015) Hydroclimatology of extreme river flows. Freshw Biol 60:2461-2476

Gellis AC (2013) Factors influencing storm-generated suspended sediment concentrations and loads in four basins of contrasting land use, humid-tropical Puerto Rico. CATENA 104:39-57

Gellis AC, Noe GB (2013) Sediment source analysis in Linganore Creek watershed, Maryland, USA, using the sediment fingerprinting approach: 2008 to 2010. J Soils Sediments 13:1735-1753

Gellis AC, Hupp CR, Pavich MJ, Landwehr JM, Banks WSL, Hubbard BE, Langland MJ, Ritchie JC, Reuter JM (2009) Sources, transport, and storage of sediment at selected sites in the Chesapeake Bay watershed. Reston, VA: US Department of the Interior, US Geological Survey Scientific Investigations Report 2008-5186:1-95

Gellis AC, Meyers MK, Noe GB, Hupp CR, Schenk ER, Myers L (2017) Storms, channel changes, and a sediment budget 
for an urban-suburban stream, difficult run, Virginia, USA. Geomorphology 278:128-148

Gray JR, Gartner JW (2009) Technological advances in suspended-sediment surrogate monitoring. Water Resour Res 45:W00D29. https://doi.org/10.1029/2008wr007063

Henley WF, Patterson MA, Neves RJ, Dennis Lemly A (2000) Effects of sedimentation and turbidity on lotic food webs: a concise review for natural resource managers. Rev Fish Sci 8(2):125-139. https://doi.org/10.1080/ 10641260091129198

Henry HAL (2007) Soil freeze-thaw cycle experiments: trends, methodological weaknesses and suggested improvements. Soil Biol Biochem 39:977-986

Historic map works (2017) http://www.historicmapworks.com/ Map/US/9686/Fairhill/. Accessed 12 Apr 2017

Inamdar SP, Singh S, Dutta S, Levia D, Mitchell M, Scott D, Bais H, McHale P (2011) Fluorescence characteristics and sources of dissolved organic matter for stream water during storm events in a forestedmid-Atlantic watershed. J Geophys Res 116:G03043. https://doi.org/10.1029/ 2011JG001735

Inamdar S, Dhillon G, Singh S, Dutta S, Levia D, Scott D, Mitchell M, Van Stan J, McHale P (2013) Temporal variation in end-member chemistry and its influence on runoff mixing patterns in a forested, Piedmont catchment. Water Resour Res 49:1828-1844. https://doi.org/10.1002/wrcr. 20158

Inamdar S, Dhillon G, Singh S, Parr T, Qin Z (2015) Particulate nitrogen exports in stream runoff exceed dissolved nitrogen forms during large tropical storms in a temperate, headwater, forested watershed. J Geophys Res. Biogeosci 120:1548-1566. https://doi.org/10.1002/2015JG002909

James LA (2013) Legacy sediment: definitions and processes of episodically produced anthropogenic sediment. Anthropocene 2:16-26

Jeong J, Bartsch S, Fleckenstein JH, Matzner E, Tenhunen JD, Lee SD, Park SK, Park JH (2012) Differential storm responses of dissolved and particulate organic carbon in a mountainous headwater stream, investigated by high-frequency, in situ optical measurements. J Geophys Res 117(G3):G03013. https://doi.org/10.1029/2012JG001999

Johnson ER, Inamdar S, Kan J, Vargas R (submitted) Particulate organic matter (POM) composition in stream runoff following large storms: role of POM sources, particle size, and event characteristics. J Geophys Res Biogeosci

Jung BJ, Lee HJ, Jeong JJ, Owen J, Kim B, Meusburger K, Alewell C, Gebauer G, Shope C, Park JH (2012) Storm pulses and varying sources of hydrologic carbon export from a mountainous watershed. J Hydrol 440-441:90-101. https://doi.org/10.1016/j.jhydrol.2012.03.030

Lawler DM (1993a) Needle ice processes and sediment mobilization on river banks: the River Ilston, West Glamorgan, UK. J Hydrol 150(1):81-114

Lawler DM (1993b) The measurement of river bank erosion and lateral channel change: a review. Earth Surf Process Landf 18(9):777-821

Liu Y, Engel BA, Flanagan DC, Gitau MW, McMillan SK, Chaubey I (2017) A review on effectiveness of best management practices in improving hydrology and water quality: needs and opportunities. Sci Total Environ 601-602:580-593
Lyons NJ, Starek MJ, Wegmann KW, Mitasova H (2015) Bank erosion of legacy sediment at the transition from vertical to lateral stream incision. Earth Surf Process Landf 40:1764-1778

Massoudieh A, Gellis A, Banks WS, Wieczorek ME (2012) Suspended sediment source apportionment in Chesapeake Bay watershed using Bayesian chemical mass balance receptor modeling. Hydrol Process. https://doi.org/10. 1002/hyp.9429

Melillo, JM, Richmond TC, Yohe GW (2014) Climate change impacts in the United States: the third National climate assessment. U.S. Global Change Research Program, p 841. https://doi.org/10.7930/j0z31wj2

Merritts D, Walter R, Rahnis M et al (2011) Anthropocene streams and base-level controls from historic dams in the unglaciated mid-Atlantic region, USA. Philos Trans R Soc A 369:976-1009

Merritts D, Walter R, Rahnis M, Cox S, et al (2013) The rise and fall of Mid-Atlantic streams: millpond sedimentation, milldam breaching, channel incision, and streambank erosion. In: De Graff, JV, Evans JE (eds), The challenges of dam removal and river restoration: geological society of america reviews in engineering geology, vol XXI, pp 183-203. https://doi.org/10.1130/2013.4121(14)

Mukundan R, Radcliffe DE, Ritchie JC, Risse LM, McKinley RA (2010) Sediment fingerprinting to determine the source of suspended sediment in a southern piedmont stream. J Environ Qual 39:1328-1337

Murphy SF, Writer JH, McCleskey RB, Martin DA (2015) The role of precipitation type, intensity, and spatial distribution in source water quality after wildfire. Environ Res Lett 10(8):084007. https://doi.org/10.1088/1748-9326/10/8/ 08400713

National weather service (2017) What is the polar vortex? http:// www.nws.noaa.gov/om/cold/polar_vortex.shtml. Accessed 21 Mar 2017

Naylor LA et al (2017) Stormy geomorphology: geomorphic contributions in an age of climate extremes. Earth Surf Process Landf 42:166-190

NOAA (2016) Winter was record warm for the contiguous U.S. http://www.noaa.gov/news/winter-was-record-warm-forcontiguous-us. Accessed 21 Mar 2017

Orth RJ, Williams MR, Marion SR et al (2010) Long term trends in submersed aquatic vegetation (SAV) in Chesapeake Bay, USA, related to water quality. Estuar Coasts 33:1144-1163. https://doi.org/10.1007/s12237-010-93114

Paul MJ, Meyer JL (2001) Streams in the urban landscape. Annu Rev Ecol Syst 32:333-365

Pizzuto J, O'Neal M (2009) Increased mid-twentieth century riverbank erosion rates related to the demise of mill dams, South River, Virginia. Geology 37:19-22. https://doi.org/ 10.1130/G25207A.1

Rasmussen PP, Gray JR, Glysson DG, Ziegler AC (2009) Guidelines and procedures for computing time-series suspended-sediment concentrations and loads from in-stream turbidity-sensor and streamflow data, U.S. Geol. Surv. Tech. Methods, Book 3, Chap. C4, p 66

Rittenburg RA, Squires AL, Boll J, Brooks ES, Easton ZM, Steenhuis TS (2015) Agricultural BMP effectiveness and dominant hydrological flow paths: concepts and a review. 
J Am Water Resour Assoc (JAWRA) 51(2):305-329. https://doi.org/10.1111/1752-1688.12293

Rowland RD, Inamdar SP, Parr TB (2017) Particulate organic matter exports from headwater catchments: role of particle size, sources and storm magnitude. Biogeochemistry 133(2):181-200. https://doi.org/10.1007/s10533-0170325-X

Science and Technology Advisory Committee (STAC), Chesapeake Bay Program (2017) Workshop on legacy sediment, Riparian Corridors, and total maximum daily loads. April 24, 2017-April 25, 2017, Annapolis, MD. http:// www.chesapeake.org/stac/workshop.php?activity_id= 276. Accessed 12 Jun 2017

Sharpley A, Jarvie HP, Buda A, May L, Spears B, Kleinman P (2013) Phosphorus legacy: overcoming the effects of past management practices to mitigate future water quality impairment. J Environ Qual 42:1308-1326

Stewart HA, Massoudieh A, Gellis A (2015) Sediment source apportionment in Laurel Hill Creek, PA, using Bayesian chemical mass balance and isotope fingerprinting. Hydrol Process 29:2545-2560

Trimble SW (1974) Man-induced soil erosion on the Southern Piedmont, 1700-1970. Soil Conservation Society of America, Ankeny, p 1974

USEPA (2016a) National summary of state information, causes of impairment in assessed rivers and streams: http:// ofmpub.epa.gov/tmdl_waters10/attains_nation_cy. control\#total_assessed_waters. Accessed 27 Mar 2017

USEPA (2016b) A manual to identify sources of fluvial sediment. In: Gellis A, Fitzpatrick F, Schubauer-Berigan J (eds). EPA/600/R-16/210, Cincinnati, Ohio. https://pubs. er.usgs.gov/publication/70182516. Accessed 27 Mar 2017

USGS-1 (2017) Stream flow data from Brandywine Creek at Wilmington, DE-https://waterdata.usgs.gov/usa/nwis/ uv?01481500

USGS-2 (2017) Stream flow data from White Clay Creek at Strikersville, PA-https://waterdata.usgs.gov/usa/nwis/ uv?01478245

Vaz MDR, Edwards AC, Shand CA, Cresser MS (1994) Changes in the chemistry of soil solution and acetic-acid extractable-P following different types of freeze-thaw episodes. Eur J Soil Sci 45:353-359

Voli MT, Wegmann KW, Bohnensteihl DR, Leithold E, Osburn CL, Polyakov V (2013) Fingerprinting the sources of suspended sediment delivery to a large municipal drinking water reservoir: falls Lake, Neuse River, North Carolina, USA. J Soils Sediments 13:1692-1707

Walling DE (2005) Tracing suspended sediment sources in catchments and river systems. Sci Total Environ 344:159-184

Walter RC, Merritts DJ (2008) Natural streams and the legacy of water-powered mills. Science 319:299-304. https://doi. org/10.1126/science. 1151716
Wang Q, Liu J (2017) Wang L (2017) An experimental study on the effects of freeze-thaw cycles on phosphorus adsorption-desorption processes in brown soil. RSC Adv. 7:37441

Waters TF (1995) Sediment in streams: sources, biological effects, and control. American Fisheries Society Monograph 7. Bethesda, MD, American Fisheries Society

Wegmann KW, Lewis RQ, Hunt MC (2012) Historic mill ponds and piedmont stream water quality: making the connection near Raleigh, North Carolina. In: Eppes MC, Bartholomew MJ (eds) From the Blue Ridge to the Coastal Plain: field Excursions in the Southeastern United States, Geological Society of America Field Guide 29, pp 93-121. https://doi. org/10.1130/2012.0029(03)

Wegmann KW et al. (2013) Legacy sediments and stream water quality: estimating volume, nutrient content, and stream bank erosion in 303(d)-impaired waterways of the North Carolina Piedmont. WRRI University of North Carolina, Report No. 435, Chapel Hill, NC

Weitzman JN, Forshay KJ, Kaye JP, Mayer PM, Koval JC, Walter RC (2014) Potential nitrogen and carbon processing in a landscape rich in milldam legacy sediments. Biogeochemistry 120:337-357. https://doi.org/10.1007/s10533014-0003-1

Wohl E (2015) Legacy effects on sediments in river corridors. Earth-Sci Rev 147:30-53

Wolman MG (1959) Factors influencing erosion of a cohesive river bank. Am J Sci 257:204-216

Wynn TM (2006) Streambank retreat: a primer, watershed update vol 4(1), AWRA hydrology \& watershed management technical committee. http://www.awra.org/ committees/techcom/watershed/pdfs/0401WU.pdf. Accessed 3 Jun 2017

Wynn TM, Mostaghimi S (2006) Effects of riparian vegetation on streambank subaerial processes in southwestern Virginia, USA. Earth Surf Process Landf 31:399-413

Yellen B, Woodruff JD, Kratz LN, Mabee SB, Morrison J, Martini AM (2014) Source, conveyance and fate of suspended sediments following Hurricane Irene. New England, USA. Geomorphology 226:124-134. https://doi.org/ 10.1016/j.geomorph.2014.07.028

Yellen B, Woodruff JD, Cook TL, Newton RM (2016) Historically unprecedented erosion from Tropical Storm Irene due to high antecedent precipitation. Earth Surf Process Landf 41:677-684

Zhang J, Tian W, Chipperfield MP, Xie F, Huang J (2016) Persistent shift of the Arctic polar vortex towards the Eurasian continent in recent decades. Nat Clim Change 6:1094-1099. https://doi.org/10.1038/nclimate3136 